\title{
What Is New in Occupational Allergic Contact Dermatitis in the Year of the COVID Pandemic?
}

\author{
Erica B. Lee ${ }^{1} \cdot$ Marissa Lobl $^{1} \cdot$ Aubree Ford ${ }^{1} \cdot$ Vincent $^{\text {DeLeo }}{ }^{2} \cdot$ Brandon L. Adler $^{2} \cdot$ Ashley Wysong $^{1}$ \\ Accepted: 23 February 2021 / Published online: 29 March 2021 \\ (C) The Author(s), under exclusive licence to Springer Science+Business Media, LLC, part of Springer Nature 2021
}

\begin{abstract}
Purpose of Review This article aims to summarize some recent trends in occupational allergic contact dermatitis (ACD), including dermatitis related to pandemic-level personal protective equipment in healthcare workers, hazards patients may experience when working from home, and occupational perspectives on the recent American Contact Dermatitis Society (ACDS) allergens of the year and ACDS Core Allergen Series updates.

Recent Findings Recent ACDS Allergens of the Year may be particularly relevant to healthcare workers, including isobornyl acrylate, which is present in glucose sensors and propylene glycol present in hand cleansers and disinfectants. Lavender, limonene, and linalool, all of which are new additions to the ACDS Core Allergen Series, have been reported as causes for occupational ACD in massage therapists and aromatherapists. Isothiazolinone allergy continues to rise in both consumer and occupational settings. Finally, the COVID-19 pandemic has resulted in a wave of occupational ACD in healthcare workers to personal protective equipment, and revealed new potential allergens for individuals working from home.

Summary Occupational allergic contact dermatitis continues to exert a significant occupational disease burden. Remaining aware of the current trends in allergens may allow for earlier recognition, diagnosis, and treatment, subsequently helping our patients to work in healthier and safer environments.
\end{abstract}

Keywords COVID-19 • Occupational allergic contact dermatitis $\cdot$ Isobornyl acrylate $\cdot$ Propylene glycol $\cdot$ Lavender $\cdot$ Limonene . Linalool $\cdot$ Isothiazolinone

\section{Introduction}

Contact dermatitis (CD) is defined as any skin disorder resulting from contact with an exogenous substance that subsequently induces an allergic or irritant response [1]. Irritant CD (ICD) occurs from direct cytotoxic effect of a chemical or physical agent and makes up about $80 \%$ of CD diagnoses, while allergic $\mathrm{CD}$ (ACD) is a type IV delayed hypersensitivity reaction that occurs only in individuals who have been previously sensitized [2]. The clinical appearance of the two may be similar. Acute

This article is part of the Topical Collection on Occupational Allergies

Ashley Wysong

Ashley.wysong@unmc.edu

1 Department of Dermatology, University of Nebraska Medical Center, 985645 Nebraska Medical Center, Omaha, NE 68198-5645, USA

2 Department of Dermatology, Keck School of Medicine of University of Southern California, Los Angeles, CA, USA skin findings typically include erythema and formation of vesicles and papules, but pustules or acneiform lesions may also present in ICD [3]. ICD is more classically associated with pain or burning with potent irritants while ACD is more pruritic, though there is significant overlap between the two, especially when ICD is produced by chronic exposure to milder irritants [4]. Regardless of the etiology, chronic exposure may eventually lead to fissuring, scaling, and lichenification of the affected areas $[2,4]$. Occupational CD commonly manifests on the hands, but the involvement of the face, or a scattered or generalized distribution, may occur [1]. Additionally, ICD and early ACD are commonly well-demarcated and confined to the area of exposure, while ACD can later extend beyond the site of contact [5]. ACD and ICD may also be differentiated by time of onset: ICD occurs rapidly over minutes to hours to potent irritants, while more commonly with milder irritants multiple exposures may lead to slowly worsening dermatitis. ACD can take 12 to $48 \mathrm{~h}$ to manifest following exposure after initial sensitization [6••] Fig 1 Histologically, ACD is most commonly characterized by spongiotic dermatitis (Fig. 2) [7]. More specific histological 
Fig. 1 Clinical image of ACD

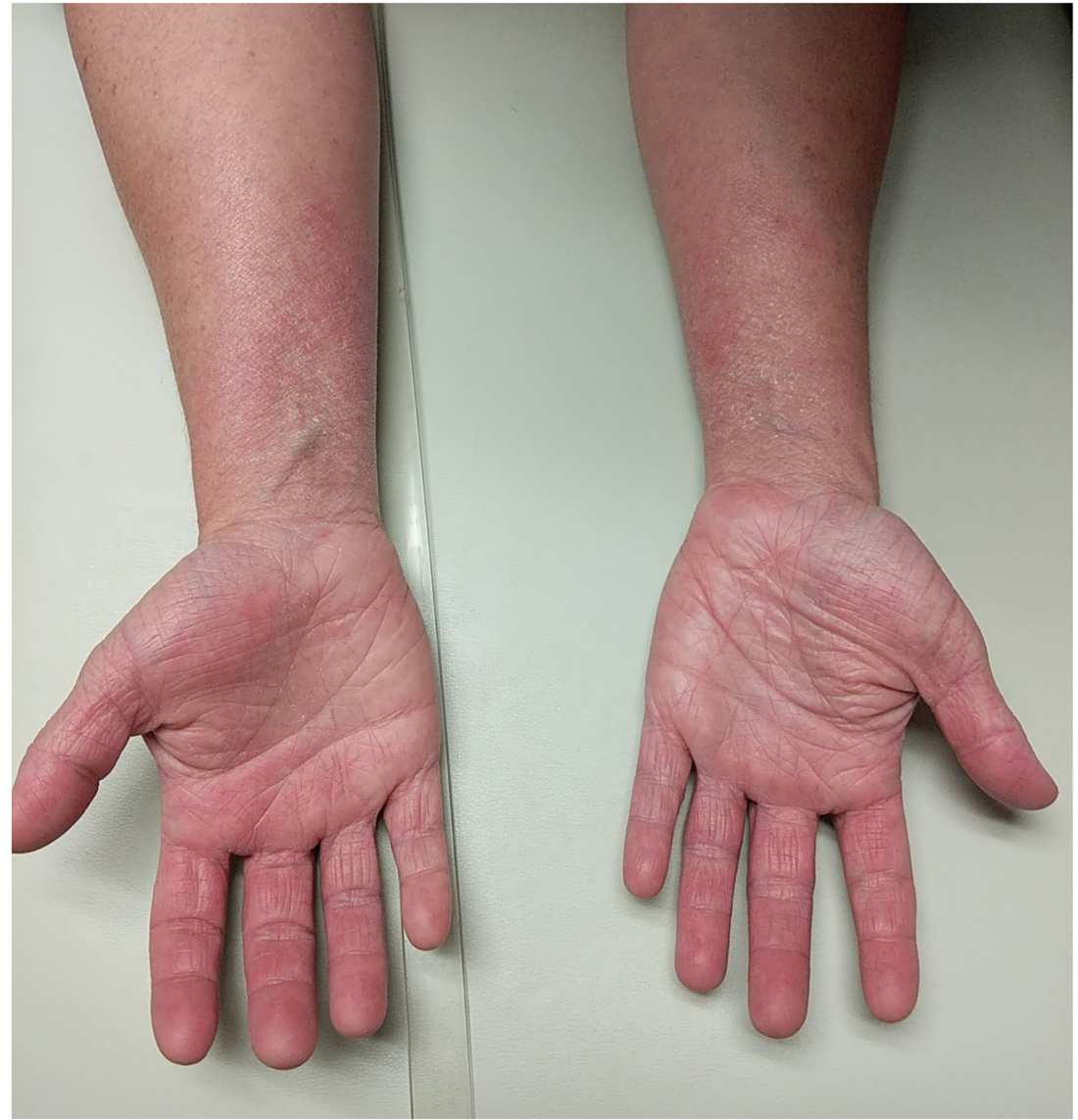

features such as Langerhans cell collections in the epidermis, eosinophilic spongiosis, and multinucleate dermal dendritic fibrohistiocytic cells have been associated with allergic CD [7, 8]. Comparatively, ICD may acutely present with necrosis of keratinocytes; however, late-stage lesions with chronic exposure to mild irritants can appear identically to ACD [9]. Thus, patch testing is necessary to definitively diagnose ACD [9].
Fig. 2 Acute spongiotic dermatitis characteristic of allergic contact dermatitis

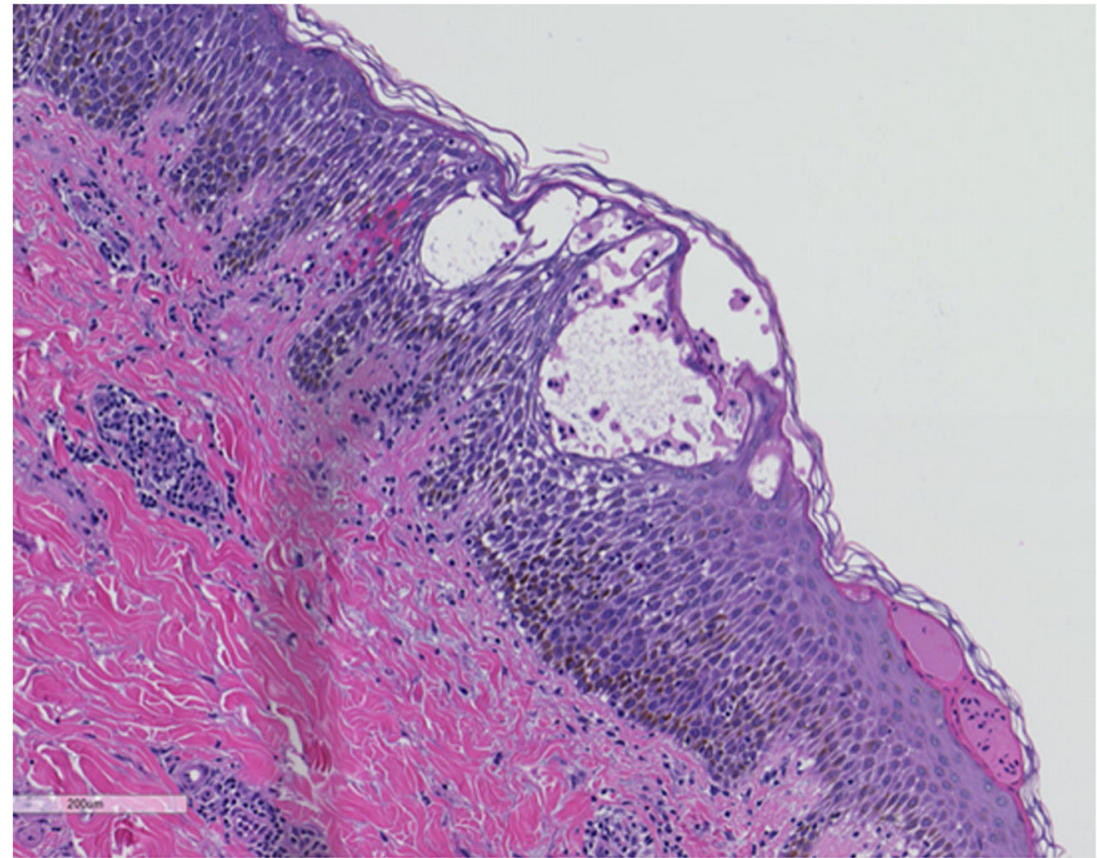




\section{Occupational CD}

$\mathrm{CD}$ is the most common occupational skin disease, composing up to $95 \%$ of all work-related cutaneous diagnoses [5]. In particular, patients working as florists, hairdressers, beauticians, cooks and food service workers, metalworkers and machinists, agricultural workers, construction workers, housekeeping personnel, and healthcare workers are at high risk for developing $\mathrm{CD}[10,11]$. Occupational $\mathrm{CD}$ can be diagnosed using criteria proposed by Mathias (Table 1) [12]. ICD is generally thought to make up most cases of occupational CD (80\%) [4] comparable to the general population; however, some suggest that ACD may be more frequent [13]. Thus, patch testing should be considered in all patients with suspected occupational dermatitis [10]. In addition to baseline patch test series such as the Thin-layer Rapid Use Epicutaneous (TRUE) test, American Contact Dermatitis Society (ACDS) Core Allergen Series, and North American Contact Dermatitis Group (NACDG) screening series, it may be necessary to test additional occupational allergens in the form of commercially available supplemental panels (such as bakery, metalworking, dentistry, hairdressing, nail technicians) and also consider direct testing of substances encountered in the work environment, when appropriate. Unknown substances should never be tested because of potential risk for skin or even systemic toxicity. For occupational products, the material safety data sheet (MSDS) should be obtained for review.

Occupational $\mathrm{CD}$ causes a significant disease burden. The Centers for Disease Control and Prevention estimate that over 13 million workers in the USA have potential exposures to chemicals damaging to the skin [14]. In addition, the North American Contact Dermatitis Group reported $10.2 \%$ of patients undergoing patch testing in 2015-2016 had

Table 1 Criteria for establishing the diagnosis of occupational CD adapted from Mathias [12]

Occupational dermatitis can be concluded as the diagnosis if it meets four of the following criteria:

1. The clinical appearance is consistent with $\mathrm{CD}$

2. Potential culprit cutaneous irritants and/or allergens are present in the workplace

3. The anatomic distribution of dermatitis is consistent with workplace skin exposure

4. The temporal relationship between exposure and onset of symptoms is consistent with $\mathrm{CD}$

5. Nonoccupational exposures are excluded as probable causes of the dermatitis

6. The dermatitis improves when absent from work exposure and re-exposure results in exacerbation

7. Patch test performed according to established guidelines demonstrates positive and relevant reactions occupationally related skin disease [15]. A 2010 systematic review found that up to half of patients report decreased quality of life, function, and social relationships related to their occupational CD [16]. Additionally, symptoms are often severe enough to require sick leave and can even lead to loss of job or change of employment [16]. Ultimately, this can produce significant individual and societal economic loss [17]. Given the high prevalence and burden of disease in occupational $\mathrm{CD}$, it is important for physicians to maintain a high index of suspicion for occupational sources in patients presenting with $\mathrm{CD}$ and be aware of the numerous potential causes. This article aims to review some of the recent trends in occupational ACD.

\section{Occupational Perspectives on ACDS Allergens of the Year (2016-2020)}

The Allergen of the Year is selected each year by the ACDS to bring attention to a specific allergen due to increasing prevalence or under-recognition, or occasionally, to highlight low prevalence of ACD (Table 2) [18]. In this section, we discuss the relevance of the five most recent allergens of the year in occupational CD.

\section{Isobornyl Acrylate (2020)}

Isobornyl acrylate is formed through reaction between acrylic acid and camphene, a bicyclic monoterpene, and is used in medical devices [19]. It has gained recent notoriety for inducing ACD in patients using insulin pumps and glucose sensors, where it is found within the plastic housing of the sensor, rather than its adhesive [20-23]. It has also been reported as an allergen in medication pumps in patients receiving continuous medications for pulmonary artery hypertension [24]. On the other hand, isobornyl acrylate as an occupational cause of ACD is less well cited in the literature. Occupational ACD caused by isobornyl acrylate in glass fiber coatings was reported in an industrial process operator [25]. A 2013 study evaluating patch test results to methacrylates and acrylates found none of 14 patients with positive patch test to at least one acrylate or methacrylate showed positivity to isobornyl acrylate at dilutions of $0.3 \%, 0.1 \%, 0.03 \%$, and $0.01 \%$ in petrolatum [25]. Given these findings, the authors did not find evidence to support adding isobornyl acrylate to the standard methacrylate/acrylate patch series, yet more recent observations have suggested the standard series often fails to capture the causative allergen [19]. It does appear that most patients with sensitivity to isobornyl acrylate have negative patch test results to other acrylates [19]. With increased use of isobornyl acrylate in the manufacturing of medical and other devices, it is possible that occupational exposure will also trend upward. 
Table 2 American Contact Dermatitis Society Allergens of the Year (2016-2020)

\begin{tabular}{llll}
\hline Year & Allergen & Common uses & Relevant occupations \\
\hline 2020 Isobornyl acrylate & Glucose sensors, medication pumps [19-23] & Manufacturing workers, healthcare workers [25] \\
$2019 \begin{array}{l}\text { Parabens ("nonallergen" } \\
\text { of the year) }\end{array}$ & $\begin{array}{l}\text { Preservative in cosmetics, foods, medications [26] } \\
\text { Cooks, food-handlers [31] }\end{array}$ & $\begin{array}{c}\text { Mechanical and motor vehicle industry, healthcare } \\
\text { workers [34, 35, 37] }\end{array}$ \\
2018 Propylene glycol & cleaners, food products [33] & Surfactants used in cosmetics, disinfectants, soaps [39] & $\begin{array}{c}\text { Aestheticians, cleaning professionals, hairdressers, } \\
\text { nurses [41] }\end{array}$ \\
2016 Cobalt & Metal used in steel, construction materials, plastics, engines, \\
medical devices [47] & $\begin{array}{c}\text { Construction workers, metalworkers, cement } \\
\text { workers, janitors [47] }\end{array}$ \\
\hline
\end{tabular}

\section{Parabens (2019)}

The 2019 allergen of the year was, for the second time since the award was established, in fact a "non-allergen", highlighting the low frequency at which parabens cause ACD. Parabens are homologous esters of $p$-hydroxybenzoic acid and due to their antimicrobial and antifungal properties are used as preservatives in cosmetics, foods, and medications [26]. Over recent years, unsubstantiated consumer concern for estrogenic and antiandrogenic effects, carcinogenesis, and endocrine disruption relating to paraben exposure has led to their removal from many cosmetics and personal care products, despite lack of definitive evidence of any harms associated with their use [27, 28]. This has led to an increased use of other preservatives, including isothiazolinones, with a subsequent increased incidence of ACD to these substances [27]. The average daily paraben exposure in individuals in the USA is estimated to be $76 \mathrm{mg}$ [29]. Despite their prevalent use, the mean positivity rate from 1992 to 2016 was only $1.1 \%$ among 55,013 patients patch tested by the NACDG [26]. Interestingly, Fisher has described a "paraben paradox" in which, because parabens are more sensitizing in damaged skin, paraben-sensitive individuals display negative patch tests to parabens and are also able to continue using parabencontaining products on intact skin [30].

Literature regarding occupational causes of paraben-induced ACD is limited to case reports of hand dermatitis in cooks and food-handlers thought to be caused by additives in the food [31]. Allergic contact dermatitis to parabens in an ultrasonic gel has also been reported, possibly placing ultrasound technicians and other healthcare workers at risk for paraben-induced ACD [32]. Overall, given the low prevalence rate, parabens may not be the highest yield allergen to patch test in suspected occupational ACD, but may be considered in patients with coexisting dermatoses that cause disruption of the skin barrier, such as atopic dermatitis, stasis dermatitis, or irritant contact dermatitis.

\section{Propylene Glycol (2018)}

Propylene glycol is an emollient and emulsifier found in many cosmetics, medications, household cleaners, and food products [33]. Although named the ACDS 2018 Allergen of the Year to raise awareness of its potential for sensitization, propylene glycol is thought to be a weak sensitizer and to further complicate things, is also a known irritant [33]. In the 2015-2016 NACDG patch test results, propylene glycol had a positivity rate of $2.8 \%$, with similar rates over the prior 10 years [15]. Longitudinal data from the NACDG looking specifically at propylene glycol found that of 810 patients who tested positive, $4.2 \%$ were occupationally related [34]. Of these patients, $38.2 \%$ were employed in the mechanical and motor vehicle industry [34].

Propylene glycol may be found in a large amount of hand cleaners and disinfectants in the healthcare setting. A study conducted evaluating the ingredients of 100 hand cleansers and disinfectants commercially available in the USA found propylene glycol to be present in approximately $15 \%$ of waterless skin soaps, $33 \%$ of water-needed skin soaps, and just under $40 \%$ of surgical scrubs [35]. In a similar study assessing allergenic ingredients in hand sanitizers used across five major Minnesota hospitals and 20 hospitals across the USA, propylene glycol was listed as an ingredient in $22 / 80$, or $27.5 \%$ of the products [36]. Schlarbaum and Hylwa found the prevalence of propylene glycol among 267 operating room scrubs and disinfectants to be $6.7 \%$ [37].

One case report has documented the potential challenges of avoiding propylene glycol in the occupational setting [38]. A 42-year-old man working as a press operator at a printing operation presented with a skin eruption on his hands and forearms, spreading to the back and scalp. He underwent patch testing and was found to have a positive reaction to propylene glycol. However, despite vigilantly avoiding work materials known to contain propylene glycol, he continued to flare. It was eventually found on a workplace visit that the patient continued to have exposure to propylene glycol through a wastewater drum containing solutions used by other presses. This case highlights a hidden source of propylene glycol capable of eliciting occupational $\mathrm{ACD}$, and the difficulty patients may have in practicing allergen avoidance. 


\section{Alkyl Glucosides (2017)}

Alkyl glucosides are surfactants that are used in cosmetics, disinfectants, and soaps due to their emulsion and foaming properties, as well as their eco-friendly nature [39]. Production is achieved by the condensation of glucose extracted from potato starch and fatty alcohol derived from coconuts [40]. While the majority of allergic contact dermatitis cases from alkyl glucosides are not from occupational exposures, occupational irritation and a personal history of atopy disrupt the epidermal barrier, which allow for increased skin permeation of alkyl glucosides [41].

A review by Alfalah et al. suggests that the most common location for allergic contact dermatitis from occupational exposure to alkyl glucosides is the hands [42]. Patients with an increased risk of allergic contact dermatitis from alkyl glucosides include those with occupations that involve regular exposure of the hands to chemicals, such as aestheticians, cleaners, hairdressers, and nurses [41]. However, other occupations may also be affected. One of the most common alkyl glucosides, decyl glucoside, has been implicated as an allergen in sunscreen ingredient Tinosorb $\mathrm{M}$, which may be relevant to persons whose occupation is primarily outdoors [43, 44]. A study using the DailyMed website performed searches to determine the exposure to alkyl glucosides for surgical personnel using operating room scrubs and disinfectants [45]. However, most of the products that contain alkyl glucosides were used on the patient, with the exception of one hand sanitizing agent [45].

A study that performed chemical analyses of several alkyl glucosides found that isobornyl acrylate was a contaminant in all three samples of raw materials tested (cocoyl glucoside, decyl glucoside, and lauryl glucoside), with an average of $500 \mathrm{ng} / \mathrm{g}$ in each tested sample [46]. While confirmation in additional studies would be useful, the data suggest that contamination may play a role in some allergies to alkyl glucosides. With the increase in focus on eco-friendly and natural products, physicians should be aware of the risk of alkyl glucoside allergies for both workers and consumers.

\section{Cobalt (2016)}

Cobalt is a magnetic metal that is widely used in many materials including high-strength steel, construction materials, plastics, engines, and medical devices [47]. Cobalt is known to be associated with occupational allergic dermatitis, with specific occupations having an increased risk such as cement workers, metalworkers, and janitors. In particular, construction workers may be exposed to cobalt in metal building materials and cement. A study of Asian cement found the concentration of cobalt to range from 9.1 to $14.2 \mu \mathrm{g} / \mathrm{g}$ [48]. An occupational dermatology service in Spain reported cobalt allergy as the second most common cause of occupational dermatitis in construction workers, occurring in 20.5\% (92/ 449) of workers [49]. A second occupational dermatology service in Brazil reported a cobalt allergy in $36.9 \%$ (17/46) of construction workers and janitors with occupational dermatitis, making it the second most common allergen in this group and supporting the findings of a previous Brazilian study [49, 50].

Metalworkers may also be at increased risk of cobalt allergy. In one study, $4 \%(6 / 150)$ of metalworkers had a positive patch test to cobalt, compared to $0 \%(0 / 150)$ of office workers [51]. Of the workers with a positive patch test, at least $67 \%$ had dermatologic symptoms [51]. Within the metal industry, workers exposed to raw materials had the highest average skin dose of cobalt $\left(1.51 \mu \mathrm{g} / \mathrm{cm}^{2}\right)$ compared to workers exposed to sintered material $\left(0.12 \mu \mathrm{g} / \mathrm{cm}^{2}\right)$ and office workers $(0.011 \mu \mathrm{g} /$ $\left.\mathrm{cm}^{2}\right)(p<0.001)$ [52]. Protective measures, such as wearing gloves and frequent handwashing, may help reduce the prevalence of cobalt sensitization in this population. In addition, legislative action to regulate occupational exposure to cobalt and other known allergenic metals may be beneficial.

\section{7 and 2020 Updates to the American Contact Dermatitis Society Core Allergen Series: Occupational Perspectives}

In 2012, the ACDS published its first core allergen series, which was designed to give clinicians a graded tool for choosing allergens to test for beyond the TRUE test [55]. The core allergen series was updated in 2017, with the removal of 3 allergens: glutaraldehyde, jasmine, and triclosan. The ACDS also added 5 new allergens: polymyxin B sulfate, lavender, sodium benzoate, benzoic acid, and ethylhexylglycerin. The most recent 2020 update includes the removal of methyldibromoglutaronitrile and addition of hydroxyisohexyl 3-cyclohexene carboxaldehyde (Lyral), limonene, linalool, carmine, benzyl salicylate, disperse yellow 3, jasmine, peppermint, pramoxine, shellac, and lauryl polyglucose (glucosides) [53••]. In the following section, we discuss the most occupationally relevant additions: lavender, limonene, and linalool.

Lavender is a plant belonging to the family Lamiaceae and the genus Lavandula that is commonly used in dried form or as an essential oil. Lavender oil is most often derived from Lavandula angustifolia, one of four species of lavender [54••, 55]. In a longitudinal study reporting patch testing results from 1990 to 1998 in Japan, the positivity rate of lavender oil was $3.7 \%$, with a stark increase in 1997 owing to use of lavender oil in aromatherapy and increased use of dried lavender [56]. Prevalence appears to be lower in North America, with one study finding a $0.3 \%$ positivity rate [57]. A more recent Australian study reported a positive patch test prevalence of $2.2 \%$ [58], Occupational ACD to lavender has been reported 
in the literature. For example, a hairdresser presenting with hand dermatitis was found to have allergy to lavender oil that was present in the shampoo used at her workplace [59]. In addition, aromatherapists and massage therapists are also at risk for developing allergic sensitization to lavender oil [60-64]. Given a recent survey of 350 massage therapists that found the 12-month prevalence of hand dermatitis to be $15 \%$, clinicians should maintain a high index of suspicion for ACD associated with this occupation [65]. In addition, clinicians should be aware that sensitization may occur through airborne exposure [66]. When testing for lavender allergy, it is important to consider that two of the main components of lavender oil, the terpenes linalool and linalyl acetate, auto-oxidize with contact to the air, creating products with greater allergen potential to nonoxidized lavender oil $[67,68]$. However, Hagvall et al. found that only $56 \%$ of patients with positive patch tests to oxidized lavender oil also tested positively against oxidized linalool and linalyl acetate, indicating there may be other chemicals involved [67]. Therefore, it may be beneficial to test patients with the specific products they contact [69].

Limonene and linalool are among the most common fragrance ingredients [70]. These natural terpenes are found in a wide variety of plants and oils. Apart from lavender, linalool is a major constituent of oils including ylang-yang, bergamot, geranium, and jasmine [71]. Limonene is found in citrus fruits such as oranges, grapefruits, and lemons [72]. They are both widely used in household and cleaning products [70], and thus are relevant from an occupational ACD standpoint among professional cleaners. One case series reported 14 patients with occupational limonene allergy among which were mechanics, maintenance workers, and vehicle assembly workers using limonene-containing cleaners. [73] Their cohort also included printers, who used machine detergents containing limonene, as well as cooks and a masseuse [73]. Foti et al. report a case of a histopathology technician with occupational ACD due to a solvent containing limonene [74]. The citrus fruit from which limonene is derived may also be a source, as seen in a laborer picking and handling these fruits [75] It appears that industrial use of limonene is increasing, which may be due to efforts to replace chlorinated hydrocarbons and chlorofluorocarbons with safer chemicals, and could produce higher rates of occupational allergy in the future [76].

\section{Isothiazolinones in Occupational ACD}

Isothiazolinones are heterocyclic chemicals featuring an aromatic ring containing sulfur and nitrogen [77]. They serve as preservatives or biocides in a wide array of cosmetic, household, and industrial products. Methylchloroisothiazolinone/ methylisothiazolinone (MCI/MI) was widely recognized as an allergen in the 1980s. In the early 2000s, the introduction of MI alone in consumer and industrial products was followed by epidemic levels of ACD to this preservative. [77] This prompted regulatory measures restricting use of MCI/MI and $\mathrm{MI}$ in consumer products in Europe, which saw a subsequent decrease in prevalence of MI contact allergy by $50 \%$ (from 6 to 3\%) between 2015 and 2017 [78]. Similar regulation has not been enacted in North America, and it is therefore unsurprising that the NACDG reported $13.4 \%$ positivity to MI in 2015-2016 [15].

Occupational ACD attributed to isothiazolinones is on the rise. Despite the strong regulatory steps taken in Europe to limit consumer exposure to $\mathrm{MCI} / \mathrm{MI}$ and $\mathrm{MI}$, labeling of industrial products is less clear, leaving workers less protected [77]. In addition, benzisothiazolinone, octylisothiazolinone, and newer isothiazolinone derivatives are being used in industrial products with greater frequency. MI is the second most common preservative found in the Danish Product Register Database, which collects information about chemical products for occupational use [79]. A German epidemiologic study found the proportion of patients with positive MCI/MI patch tests associated with occupational exposure increased significantly from $26.1 \%$ in $2013-2014$ to $39.4 \%$ in $2017-2018$ [80]. In the USA, patients with positive patch test to MCI/ MI or MI were significantly more likely to have occupationally related skin disease compared to the general patch-tested population [81]. Professions at particular risk include hairdressers, cosmeticians, and painters [80]. Manufacturing workers may also be at risk; one report documents an outbreak of ACD among 8 water bottling plant employees due to excess levels of MCI/MI in the cooling system [82]. Another recent case report details a patient with hand dermatitis caused by $\mathrm{MCI} / \mathrm{MI}$ and MI in rubber assembly lubricant [83]. Occupational CD related to MI has also been seen in patients working in factories making "flower food" and boxes [84, 85].

The wide usage of isothiazolinones as preservatives has resulted in occupational exposure in other professions as well. Numerous reports of these substances in cleaning products place cleaning professionals at particular hazard [86, 87]. Products used in metalworking may also contain isothiazolinones, including emulsifying oils and stainless steel aerosol sprays $[88,89]$. Isothiazolinones may also be present in ultrasound gel, exposing ultrasound technicians and other healthcare workers to possible sensitization [90]. Given their ubiquity, it is important to maintain a high level of suspicion for ACD related to workplace exposure to isothiazolinones.

\section{Occupational Allergic CD in Health Care Workers}

\section{Overview}

The SARS-CoV-2 (COVID-19) pandemic has highlighted the high potential for occupational skin disease among HCWs. An 
early study from China revealed the prevalence of skin damage caused by infection prevention measures among 542 front-line HCWs was a staggering 97\% [91]. The most common sites of damage were the nasal bridge, cheeks, hands, and forehead. Wearing N95 masks or goggles for greater than $6 \mathrm{~h}$ at a time increased risk for skin damage [91]. In a survey of 404 Chinese HCWs, nearly half reported mask-related skin reactions [92]. Symptoms suggestive of $\mathrm{CD}$ such as itch, redness, or rash were frequent, occurring in $14.9 \%, 12.6 \%$, and $12.4 \%$ of patients, respectively [92]. A smaller sample of 61 Chinese subjects reported slightly higher prevalence of facial itching (27.9\%), dry skin (24.6\%), and rash (16.4\%) related to N95 mask use [93]. This cohort also reported reactions to latex gloves at a rate of $88.5 \%$, with over half reporting dry skin and about a quarter developing rash. Adverse skin reactions to disposable protective clothing occurred in $60.7 \%$ of $\mathrm{HCWs}$ in the study, with approximately one-third reporting itching and $11.5 \%$ reporting rash [93]. HCWs in hospitals facing higher patient volumes compared to those with less COVID patients reported higher rates of adverse skin reactions, possibly due to longer working hours necessitating greater use of personal protective equipment (PPE) [94]. Following early studies from China, other countries also reported high rates of skin reactions among HCWs since the onset of the pandemic $[95,96]$. Data regarding the exact frequency of ACD in HCWs during the COVID-19 pandemic are limited. Singh et al. diagnosed 3 of 43 HCWs involved with care of COVID patients with ACD through teledermatology visits; however, these diagnoses were not confirmed with patch testing [96].

\section{Gloves}

Data suggest that HCWs may experience occupational ACD at higher rates compared to other professions, and also may be more likely to develop hand dermatitis [97, 98]. Gloves are a well-known cause of occupational hand ACD among HCWs. Major glove-related allergens reported among HCWs include rubber accelerator chemicals such as thiurams, carbamates, benzothiazoles, guanidines, and thioureas $[99,100]$. Rubber accelerators are found in both natural rubber latex and nonlatex (e.g., nitrile) gloves, but are not present in vinyl gloves. Latex itself predominantly induces type I hypersensitivity reactions, with far fewer reports of ACD. A 2002 survey-based study conducted among hospital employees showed nearly one-quarter of 1294 workers reported gloveinduced cutaneous symptoms [101]. Of patients experiencing symptoms, $9.1 \%$ were found to have positive skin prick tests to latex glove extracts, and $10.5 \%$ had positive patch tests to rubber-related allergens [101]. However, more recent data suggests that allergen sensitization may be more prevalent. Patch test data from $44 \mathrm{HCWs}$ with hand dermatitis after wearing gloves showed $84 \%$ reacted to carba mix, $86 \%$ reacted to 1,3-diphenylguanadine, and 30\% reacted to thiuram mix [102]. Another study found that 17 of $22 \mathrm{HCWs}$ with occupational ACD of the hands were allergic to gloverelated rubbers [103]. Data from the NACDG from 1998 to 2004 showed thiuram mix and carba mix were the most common relevant allergens, occurring in $8.87 \%$ and $5.43 \%$ of HCWs undergoing patch testing, respectively [104]. Given the high incidence of sensitization to thiurams in gloves, manufacturers have since begun to preferentially use other rubber accelerators. In the USA, a recent study found that carbamates represented the most common accelerators in medical and surgical gloves, whereas thiurams were used in a much smaller minority [105]. In addition to gloves, HCWs may also be exposed to rubber compounds through contact with medical supplies such as syringes, tubing, and catheters [99], as well as surgical scrub sponges [106].

\section{Hand Sanitizing Agents}

Studies suggest a wide array of allergens may be present in medical hand cleaners $[35,36]$. Quaternary ammonium compounds, a group which includes benzalkonium chloride, were the most common active ingredients in over 200 EPAregistered disinfectants approved for SARS-CoV-2 [107, 108]. Traditionally considered to be primarily irritant in nature, recent studies have suggested rising rates of sensitization to benzalkonium chloride $[109,110]$. Fragrance, one of the most common allergens based on epidemiologic studies conducted by the NACDG [15], was found in half of 42 medical waterless hand soaps in one study [35]. Moreover, it was found in $40 \%$ of hand sanitizers evaluated across 25 hospitals [36]. Additional pertinent allergens within the ACDS Core Allergens [54] include sodium benzoate and propylene glycol [36]. Tocopherol (vitamin E), added to hand sanitizers to reduce irritation, is also frequently present in medical hand sanitizers and is part of the ACDS Core Allergen Series. However, it only has an allergy rate of $0.5 \%$, so it may be less clinically relevant $[15,35,36]$. Kadivar and colleagues additionally report formaldehyde-releasing preservatives and cocamide diethanolamine (DEA) as relevant allergens present in hand cleansers [97]. Data from the NACDG demonstrate the rates of occupational ACD due to chloroxylenol and cocamide DEA, present in hand sanitizers and cleansers, were higher among HCWs compared to non-HCWs [104]. Other potential allergens include propylene glycol, cocamidopropyl betaine, and chlorhexidine [35].

\section{Masks}

Less well documented is ACD related to surgical masks and other forms of PPE. Case reports have identified ACD likely caused by rubber accelerators in elastic bands of masks [111, 112]. In addition, dibromodicyanobutane, found in the 
adhesive of surgical masks, has also been reported to cause $\operatorname{ACD}[113,114]$. ACD from formaldehyde in a polypropylene surgical mask was recently reported in the context of COVID19 [115]. Wearing of N95 masks is thought to have significant short-term effects on the skin, including increased skin hydration, transepidermal water loss, $\mathrm{pH}$, and sebum secretion [116]. One survey-based study of HCWs during the COVID-19 pandemic found that $81.7 \%$ of respondents reported some type of skin damage to the cheeks following use of an $\mathrm{N} 95$ for greater than $6 \mathrm{~h}$ ( [91]. ICD appears to be more common with regard to N95 masks; however, sensitization to formaldehyde liberated from the mask fabric has been reported [117, 118]. Additionally, a case report during the COVID-19 pandemic documented ACD to the polyurethane sponge inside an N95 mask [119]. A recent systematic review evaluating occupational dermatoses caused by facial PPE also identifies nickel and cobalt as potential allergens present in N95 masks [120].

\section{Treatment and Prevention}

The primary treatment for ACD is avoidance of the allergen [121]. It can be challenging for patients to determine which products may be safe to use, especially because substances often have long and sometimes multiple names. For occupational products and PPE, complete ingredients other than those listed on the MSDS may not be available. Thus, patient education is key. The ACDS has created a database, the Contact Allergen Management Program (CAMP), which allows for generation of customized safe product lists for patients patch tested by its members [121]. Complete resolution of dermatitis following allergen avoidance may take several weeks to months. During this time, adjunctive medical treatment of ACD includes topical corticosteroids and topical calcineurin inhibitors [121]. A short (2-3 weeks) course of oral corticosteroids may be required for symptom relief in acute, severe ACD; shorter tapers may be followed by rebound flares. Prolonged use of systemic corticosteroids should be avoided in ACD given the associated side effect profile. While antihistamines do not directly act on ACD-associated pruritus, sedating antihistamines may provide some relief. Emollients and barrier creams reduce xerosis and pruritus.

Because measures to prevent infection transmission are critical for HCWs taking care of COVID patients, avoidance of allergens can be challenging. To minimize the risk of sensitization and irritation from hand hygiene, the ACDS and CDC recommend alcohol-based hand sanitizers with moisturizers and the use of a moisturizer immediately after handwashing [122]. Prior to donning gloves, only waterbased moisturizers should be applied, as oil-based products can cause the rubber to break down. Additionally, antibacterial soaps should be avoided to reduce the risk of allergic skin reactions [107]. HCWs allergic to rubber accelerators can use accelerator-free gloves or switch to vinyl-based gloves, which do not contain accelerators and are thought to confer a lower risk of $\mathrm{ACD}[122,123]$; however, some studies have suggested they possess greater potential for allergenicity than is usually assumed, largely undetected due to unidentified or rare associated allergens [124]. Given that prolonged exposure time to N95 masks and gloves may be a risk factor for developing adverse skin reactions, efforts should be made to implement breaks and reduce overall time spent in this protective equipment. Further development of low allergen or allergenfree materials may also be beneficial.

\section{Occupational Allergic Dermatitis in the COVID-19 Work from Home Era}

Since the World Health Organization (WHO) declared SARSCoV-2 a pandemic on March 11, 2020, many companies have encouraged or even required employees to work from home. A nationwide global positioning system (GPS) study in the USA from February 24, 2020, to April 29, 2020, confirmed that social distancing and stay-at-home measures were associated with a $29 \%$ decrease in SARS-CoV-2 incidence (adjusted incidence rate ratio (IRR) $0.71,95 \% \mathrm{CI} 0.57-0.87$ ) and a $35 \%$ decrease in SARS-CoV-2 mortality (adjusted IRR 0.65, 95\% CI 0.55-0.76) [125]. Furthermore, a modeling study performed by Koo et al. in Singapore demonstrated that workplace distancing is more effective than school closure in preventing the spread of SARS-CoV-2 [126]. Given the strong data supporting remote work, physicians treating patients with occupational allergic dermatitis may be faced with new challenges unique to this shift to remote work for many sectors.

Laptop computers are often used to perform remote work and several reports have associated laptops with allergic contact dermatitis, especially from metals. A 2016 study of five brands of laptop computers performed nickel spot tests to determine the amount of metal released from each computer [127]. Results demonstrated that HP, Dell, and Apple computers all released nickel in the wrist supports of many computers [127]. Rates of nickel release over time following exposure to artificial sweat were measured for HP computers and were highest after $2 \min \left(319 \mathrm{ng} / \mathrm{cm}^{2} / \mathrm{h}\right)$ but declined over time [127]. One case of nickel-associated laptop dermatitis occurred in a 50 year-old woman without a history of atopy who developed pruritic vesicular dermatitis several weeks after obtaining an Apple MacBook Pro laptop [128]. The dermatitis was confined to the areas of the hand that had sustained contact with metal components of the laptop and resolved after the patient stopped using the laptop [128]. As nickel allergies are present in 8-19\% of adults, awareness and efforts to decrease exposure, such as recommending computer skins and covers, may prevent symptoms for these individuals 
[129]. In addition to reports of nickel-related allergies, other causes of allergic contact dermatitis secondary to laptop/ computer use have been documented, including ACD to dialkyl thiourea in a wrist rest [130], diphenylthiourea in neoprene rubber used in a mouse pad [131], and resorcinol monobenzoate in a computer mouse $[132,133]$. As the use of laptop computers and accessories is likely to increase due to the shift to remote work, physician awareness of these manifestations may lead to improved outcomes for patients through early allergen identification and avoidance.

While rare, several other remote work devices have been associated with allergic contact dermatitis. One such example is a case of occupational allergic contact dermatitis of the auricle and auditory canal resulting from a headset containing thiuram [134]. iPads are increasing in popularity for occupational use, although occupational ACD has not yet been reported. One report of a pediatric patient details allergic contact dermatitis arising from use of an iPad, which tested positive for nickel [135]. The patient's symptoms resolved by using the Smart Case for the iPad [135]. While relatively uncommon at present, there may be a future increase in occupational allergic contact dermatitis arising from technological products that are used for remote work. Maintaining a high level of suspicion and knowledge of the scope of these disease presentations may improve patient management.

\section{Conclusion}

ACD is a common occupational dermatosis associated with significant disease burden in the workforce. In the current global setting, clinicians should be particularly cognizant of allergen exposure in healthcare workers on the frontlines of the COVID-19 pandemic as well as the potential allergens encountered when working from home. Additionally, remaining up to date with current trends in allergens as a whole may assist in early recognition, diagnosis, and treatment of ACD, allowing our patient population to work in healthier, safer environments.

Acknowledgements We thank Dr. John Moesch for providing the image of acute spongiotic dermatitis.

\section{Declarations}

Human and Animal Rights and Informed Consent This article does not contain any studies with human or animal subjects performed by any of the authors.

Conflict of Interest The authors declare no competing interests.

\section{References}

Papers of particular interest, published recently, have been highlighted as:

- Of major importance

1. Fonacier L, Bernstein DI, Pacheco K, Holness DL, Blessing-Moore J, Khan D, et al. Contact dermatitis: a practice parameter-update 2015. J Allergy Clin Immunol Pract [Internet]. American Academy of Allergy, Asthma and Immunology; 2015 [cited 2020 Aug 12];3: S1-39. Available from: https://www.pubmed-ncbi-nlm-nih-gov. library1.unmc.edu/25965350/. Accessed 31 Aug 2020

2. Lushniak BD. Occupational contact dermatitis [Internet]. Dermatol. Ther. Dermatol Ther; 2004 [cited 2020 Aug 12]. p. 272-7. Available from: https://www.pubmed.ncbi.nlm.nih.gov/ 15186373/. Accessed 31 Aug 2020

3. Slodownik D, Lee A, Nixon R. Irritant contact dermatitis: a review [Internet]. Australas. J. Dermatol. John Wiley \& Sons, Ltd; 2008 [cited 2020 Oct 13]. p. 1-11. Available from: https://www. onlinelibrary.wiley.com/doi/full/10.1111/j.1440-0960.2007. 00409.x. Accessed 31 Aug 2020

4. Sasseville D. Occupational contact dermatitis. Allergy, Asthma Clin Immunol [Internet]. BioMed Central; 2008 [cited 2020 Aug 13];4:59. Available from: http://www.aacijournal. biomedcentral.com/articles/10.1186/1710-1492-4-2-59. Accessed 31 Aug 2020

5. Bains SN, Nash P, Fonacier L. Irritant contact dermatitis [Internet]. Clin. Rev. Allergy Immunol. Humana Press Inc.; 2019 [cited 2020 Aug 12]. p. 99-109. Available from: doi:https://doi.org/10.1007/ s12016-018-8713-0. Accessed 31 Aug 2020

$6 . \bullet$ Hollins LC, Flamm A. Occupational contact dermatitis: evaluation and management considerations [Internet]. Dermatol. Clin. W.B. Saunders; 2020 [cited 2020 Oct 13]. p. 329-38. Available from: https://www.pubmed.ncbi.nlm.nih.gov/32475511/. Accessed 31 Aug 2020. Great overview of workup and treatment for occupational contact dermatitis.

7. Rosa G, Fernandez AP, Vij A, Sood A, Plesec T, Bergfeld WF, et al. Langerhans cell collections, but not eosinophils, are clues to a diagnosis of allergic contact dermatitis in appropriate skin biopsies. J Cutan Pathol [Internet]. Blackwell Publishing Ltd; 2016 [cited 2020 Aug 25];43:498-504. Available from: https://www. wiley.com/10.1111/cup.12707. Accessed 31 Aug 2020

8. Wildemore JK, Junkins-Hopkins JM, James WD. Evaluation of the histologic characteristics of patch test confirmed allergic contact dermatitis. J Am Acad Dermatol. Mosby Inc. 2003;49:243-8.

9. Frings VG, Böer-Auer A, Breuer K. Histomorphology and immunophenotype of eczematous skin lesions revisited - skin biopsies are not reliable in differentiating allergic contact dermatitis, irritant contact dermatitis, and atopic dermatitis. Am J Dermatopathol [Internet]. Lippincott Williams and Wilkins; 2018 [cited 2020 Oct 13];40:7-16. Available from: http://www.journals.lww.com/ 00000372-201801000-00002. Accessed 31 Aug 2020

10. Rashid RS, Shim TN. Contact dermatitis. BMJ [Internet]. BMJ Publishing Group; 2016 [cited 2020 Aug 13];353. Available from: http://www.bmj.com/. Accessed 31 Aug 2020

11. Chu C, Marks JG, Flamm A. Occupational contact dermatitis: common occupational allergens. Dermatol. Clin. W.B. Saunders. 2020;38(3):339-49.

12. Toby Mathias CG. Contact dermatitis and workers' compensation: criteria for establishing occupational causation and aggravation. J Am Acad Dermatol. Mosby. 1989;20:842-8.

13. Kucenic MJ, Belsito D V. Occupational allergic contact dermatitis is more prevalent than irritant contact dermatitis: a 5-year study. J Am Acad Dermatol [Internet]. Elsevier; 2002 [cited 2020 
Aug 13];46:695-9. Available from: http://www.jaad.org/article/ S0190962202083366/fulltext. Accessed 31 Aug 2020

14. Skin Exposures and Effects $\mid$ NIOSH $\mid$ CDC [Internet]. [cited 2020 Aug 14]. Available from: https://www.cdc.gov/niosh/topics/skin/. Accessed 31 Aug 2020

15. DeKoven JG, Warshaw EM, Zug KA, Maibach HI, Belsito D V., Sasseville D, et al. North American Contact Dermatitis Group Patch Test Results: 2015-2016 [Internet]. Dermatitis. Lippincott Williams and Wilkins; 2018 [cited 2020 Aug 31]. p. 297-309. Available from: https://www.pubmed.ncbi.nlm.nih.gov/ 30422882/. Accessed 31 Aug 2020

16. Nicholson PJ, Llewellyn D, English JS. Evidence-based guidelines for the prevention, identification and management of occupational contact dermatitis and urticaria [Internet]. Contact Dermatitis. John Wiley \& Sons, Ltd; 2010 [cited 2020 Oct 13]. p. 177-86. Available from: https://www.onlinelibrary.wiley.com/doi/full/10.1111/j.16000536.2010.01763.x. Accessed 31 Aug 2020

17. Holness DL. Occupational Dermatosis [Internet]. Curr. Allergy Asthma Rep. Current Medicine Group LLC 1; 2019 [cited 2020 Jul 14]. p. 1-8. Available from: doi:https://doi.org/10.1007/ s11882-019-0870-6. Accessed 31 Aug 2020

18. Militello M, Hu S, Laughter M, Dunnick CA. American Contact Dermatitis Society Allergens of the Year 2000 to 2020 [Internet]. Dermatol. Clin. W.B. Saunders; 2020 [cited 2020 Oct 13]. p. 30920. Available from: https://www.pubmed.ncbi.nlm.nih.gov/ 32475509/. Accessed 31 Aug 2020

19. Aerts O, Herman A, Mowitz M, Bruze M, Goossens A. Isobornyl Acrylate. Dermatitis [Internet]. Lippincott Williams and Wilkins; 2020 [cited 2020 Sep 1];31:4-12. Available from: http://www. journals.lww.com/10.1097/DER.0000000000000549. Accessed 31 Aug 2020

20. Herman A, Baeck M, de Montjoye L, Bruze M, Giertz E, Goossens A, et al. Allergic contact dermatitis caused by isobornyl acrylate in the Enlite glucose sensor and the Paradigm MiniMed Quick-set insulin infusion set. Contact Dermatitis [Internet]. Blackwell Publishing Ltd; 2019 [cited 2020 Sep 1];81:432-7. Available from: https://www.pubmed.ncbi.nlm.nih.gov/ 31385313/. Accessed 31 Aug 2020

21. Mowitz M, Fornander L, Hosseiny S, Ryberg K, Bruze M. Patch testing with isobornyl acrylate in 16 swedish patients with contact dermatitis from glucose sensors and/or insulin pumps. Acta Derm Venereol [Internet]. Medical Journals/Acta D-V; 2019 [cited 2020 Sep 1];99:1286-7. Available from: https://www.pubmed.ncbi.nlm. nih.gov/31289841/. Accessed 31 Aug 2020

22. Raison-Peyron N, Mowitz M, Bonardel N, Aerts O, Bruze M. Allergic contact dermatitis caused by isobornyl acrylate in OmniPod, an innovative tubeless insulin pump. Contact Dermatitis [Internet]. Blackwell Publishing Ltd; 2018 [cited 2020 Sep 1];79:7680. Available from: https://www.pubmed.ncbi.nlm.nih.gov/ 29635853/. Accessed 31 Aug 2020

23. Ulriksdotter J, Svedman C, Bruze M, Glimsjö J, Källberg K, Sukakul T, et al. Contact dermatitis caused by glucose sensors15 adult patients tested with a medical device patch test series. Contact Dermatitis [Internet]. Blackwell Publishing Ltd; 2020 [cited 2020 Sep 1]; Available from: https://www.pubmed.ncbi. nlm.nih.gov/32608015/. Accessed 31 Aug 2020

24. Malinauskiene L, Šlekyte G, Mowitz M, Isaksson M, Zablockis R. Allergic contact dermatitis caused by isobornyl acrylate in two patients treated for idiopathic pulmonary arterial hypertension. Contact Dermatitis [Internet]. Blackwell Publishing Ltd; 2020 [cited 2020 Sep 1];83:170-1. Available from: https://www.onlinelibrary.wiley.com/ doi/abs/10.1111/cod.13617. Accessed 31 Aug 2020

25. Christoffers WA, Coenraads P-J, Schuttelaar M-LA. Two decades of occupational (meth)acrylate patch test results and focus on isobornyl acrylate. Contact Dermatitis [Internet]. John Wiley \& Sons, Ltd; 2013 [cited 2020 Sep 1];69:86-92. Available from: .https://www.wiley. com/10.1111/cod.12023. Accessed 31 Aug 2020

26. Fransway AF, Fransway PJ, Belsito D V., Warshaw EM, Sasseville D, Fowler JF, et al. Parabens. Dermatitis [Internet]. Lippincott Williams and Wilkins; 2019 [cited 2020 Sep 1];30:331. Available from: http://www.journals.lww.com/01206501201901000-00002. Accessed 31 Aug 2020

27. Sasseville D, Alfalah M, Lacroix J-P. "Parabenoia" debunked, or "who's afraid of parabens?" dermatitis [Internet]. Lippincott Williams and Wilkins; 2015 [cited 2020 Oct 13];26:254-9. Available from: http://www.journals.lww.com/01206501201511000-00003. Accessed 31 Aug 2020

28. Fransway AF, Fransway PJ, Belsito D V., Warshaw EM, Sasseville D, Fowler JF, et al. Parabens. Dermatitis. Lippincott Williams and Wilkins; 2019. p. 3-31.

29. Cashman AL, Warshaw EM. Parabens: a review of epidemiology, structure, allergenicity, and hormonal properties. Dermatitis [Internet]. 2005 [cited 2020 Sep 2];16:55-66. Available from: https://www. pubmed.ncbi.nlm.nih.gov/16036114/. Accessed 31 Aug 2020

30. Fisher AA. Paraben dermatitis due to a new medicated bandage: the "paraben paradox." Contact Dermatitis [Internet]. Contact Dermatitis; 1979 [cited 2020 Sep 2];5:273-4. Available from: https://www. pubmed.ncbi.nlm.nih.gov/498778/. Accessed 31 Aug 2020

31. Fisher A. Dermatitis of the hands from food additives. Cutis [Internet]. 1982 [cited 2020 Sep 2];30:304. Available from: https://www. pubmed.ncbi.nlm.nih.gov/7172732/. Accessed 31 Aug 2020

32. Eguino P, Sanchez A, Agesta N, Lasa O, Raton JA, Diaz-Perez JL. Allergic contact dermatitis due to propylene glycol and parabens in an ultrasonic gel - PubMed. Contact Dermaititis [Internet]. 2003 [cited 2020 Sep 2];48:290. Available from: https://www.pubmed. ncbi.nlm.nih.gov/12931739/. Accessed 31 Aug 2020

33. McGowan MA, Scheman A, Jacob SE. Propylene glycol in contact dermatitis. Dermatitis [Internet]. Lippincott Williams and Wilkins; 2018 [cited 2020 Sep 2];29:6-12. Available from: http://www.journals.lww.com/01206501-201801000-00003. Accessed 31 Aug 2020

34. Warshaw EM, Botto NC, Maibach HI, Fowler JF, Rietschel RL, Zug $\mathrm{KA}$, et al. Positive patch-test reactions to propylene glycol: a retrospective cross-sectional analysis from the North American Contact Dermatitis Group, 1996 to 2006. Dermatitis. 2009;20:14-20.

35. Rodriguez-Homs LG, Atwater AR. Allergens in medical hand skin cleansers [Internet]. Dermatitis. Lippincott Williams and Wilkins; 2019 [cited 2020 Aug 24]. p. 336-41. Available from: https://www.pubmed.ncbi.nlm.nih.gov/31724988/. Accessed 31 Aug 2020

36. Voller LM, Schlarbaum JP, Hylwa SA. Allergenic ingredients in health care hand sanitizers in the United States. Dermatitis. 2020;Publish Ah:1-9.

37. Schlarbaum JP, Hylwa SA. Allergic contact dermatitis to operating room scrubs and disinfectants. Dermatitis [Internet]. Lippincott Williams and Wilkins; 2019 [cited 2020 Sep 3];30: 363-70. Available from: https://www.pubmed.ncbi.nlm.nih.gov/ 31724990/. Accessed 31 Aug 2020

38. Noiles K, Kudla I, De Koven J. Propylene glycol dermatitis in the printing industry: the fundamental role of a workplace visit . Dermatitis [Internet]. 2010 [cited 2020 Sep 3];21:E1-4. Available from: https://www.pubmed.ncbi.nlm.nih.gov/ 20137732/. Accessed 31 Aug 2020

39. Loranger C, Alfalah M, Le Bouedec Ferrier MC, Sasseville D. Alkyl glucosides in contact dermatitis [Internet]. Dermatitis. Lippincott Williams and Wilkins; 2017 [cited 2020 Sep 1]. p. 513. Available from: https://www.pubmed.ncbi.nlm.nih.gov/ 27775979/. Accessed 31 Aug 2020

40. Sasseville D. Alkyl Glucosides. Dermatitis [Internet]. Lippincott Williams and Wilkins; 2017 [cited 2020 Sep 1];28:296. Available 
from: http://www.journals.lww.com/01206501-20170700000018. Accessed 31 Aug 2020

41. Bhoyrul B, Solman L, Kirk S, Orton D, Wilkinson M. Patch testing with alkyl glucosides: concomitant reactions are common but not ubiquitous. Contact Dermatitis [Internet]. Blackwell Publishing Ltd; 2019 [cited 2020 Sep 1];80:286-90. Available from: https://www.wiley.com/10.1111/cod.13186. Accessed 31 Aug 2020

42. Alfalah M, Loranger C, Sasseville D. Alkyl Glucosides. Dermatitis [Internet]. Lippincott Williams and Wilkins; 2017 [cited 2020 Sep 1];28:3-4. Available from: http://www.journals. lww.com/01206501-201701000-00002. Accessed 31 Aug 2020

43. Andrade $\mathrm{P}$, Gonçalo M, Figueiredo A. Allergic contact dermatitis to decyl glucoside in Tinosorb $M$ ®. Contact Dermatitis [Internet]. John Wiley \& Sons, Ltd; 2010 [cited 2020 Sep 1];62:119-20. Available from: https://www/wiley.com/10.1111/j.1600-0536. 2009.01680.x. Accessed 31 Aug 2020

44. Monteiro AF, Paulino M, Máquina A, Amaro C, Viana I. Allergic contact dermatitis to decyl glucoside: still an important allergen in Tinosorb M. Contact Dermatitis [Internet]. Blackwell Publishing Ltd; 2020 [cited 2020 Oct 26];82:126-8. Available from: https:// www.pubmed.ncbi.nlm.nih.gov/31566773/. Accessed 31 Aug 2020

45. Schlarbaum JP, Hylwa SA. Allergic contact dermatitis to operating room scrubs and disinfectants. Dermatitis [Internet]. Lippincott Williams and Wilkins; 2019 [cited 2020 Sep 1];30: 363-70. Available from: https://www.pubmed.ncbi.nlm.nih.gov/ 31724990/. Accessed 31 Aug 2020

46. Foti C, Romita P, Rigano L, Zimerson E, Sicilia M, Ballini A, et al. Isobornyl acrylate: an impurity in alkyl glucosides. Cutan Ocul Toxicol [Internet]. Taylor and Francis Ltd; 2016 [cited 2020 Sep 1];35:115-9. Available from: https://www.tandfonline.com/ doi/abs/10.3109/15569527.2015.1055495. Accessed 31 Aug 2020

47. Fowler JF. Cobalt. Dermatitis [Internet]. Lippincott Williams and Wilkins; 2016 [cited 2020 Sep 1];27:3-8. Available from: http:// www.journals.lww.com/01206501-201601000-00002. Accessed 31 Aug 2020

48. Goh CL, Kwok SF, Gan SL. Cobalt and nickel content of Asian cements. Contact Dermatitis [Internet]. John Wiley \& Sons, Ltd; 1986 [cited 2020 Sep 1];15:169-72. Available from: .https:// www.wiley.com/10.1111/j.1600-0536.1986.tb01319.x. Accessed 31 Aug 2020

49. Condé-Salazar L, Guimaraens D, Villegas C, Rumero A, Gonzalez MA. Occupational allergic contact dermatitis in construction workers. Contact Dermatitis [Internet]. Contact Dermatitis; 1995 [cited 2020 Sep 1];33:226-30. Available from: https://www.pubmed.ncbi.nlm.nih.gov/8654071/. Accessed 31 Aug 2020

50. das Graças Mota Melo M, Villarinho ALCF, da Costa Leite I. Sociodemographic and clinical profile of patients with occupational contact dermatitis seen at a work-related dermatology service, 2000 - 2014. An Bras Dermatol [Internet]. NLM (Medline); 2019 [cited 2020 Sep 1];94:147-56. Available from: https://www. pmc/articles/PMC6486076/?report=abstract. Accessed 31 Aug 2020

51. Papa G, Romano A, Quaratino D, Di Fonso M, Viola M, Sernia S, et al. Contact dermatoses in metal workers. Int J Immunopathol Pharmacol [Internet]. Biomedical Research Press s.a.s.; 2000 [cited 2020 Sep 1];13:43-7. Available from: https://www.pubmed. ncbi.nlm.nih.gov/12749778/. Accessed 31 Aug 2020

52. Kettelarij J, Midander K, Lidén C, Julander A. Contamination of skin and surfaces by cobalt in the hard metal industry. Contact Dermatitis [Internet]. Blackwell Publishing Ltd; 2018 [cited 2020 Sep 1];79:226-31. Available from: .httsp://www.wiley. com/10.1111/cod.13056. Accessed 31 Aug 2020
53.• Schalock PC, Dunnick CA, Nedorost S, Brod B, Warshaw E, Mowad C, et al. American contact dermatitis society core allergen series: 2020 update [Internet]. Dermatitis. Lippincott Williams and Wilkins; 2020 [cited 2020 Oct 14]. p. 279-82. Available from: https://www.pubmed.ncbi.nlm.nih.gov/32947457/. Accessed 31 Aug 2020. ACDS Core Allergen Series 2020 Update.

54.• Schalock PC, Dunnick CA, Nedorost S, Brod B, Warshaw E, Mowad C. American contact dermatitis society core allergen series. Dermatitis [Internet]. Lippincott Williams and Wilkins; 2017 [cited 2020 Aug 25];28:141-3. Available from: http://www. journals.lww.com/01206501-201703000-00005. Accessed 31 Aug 2020. ACDS Core Allergen Series 2017 Update.

55. Wu PA, James WD. Lavender [Internet]. Dermatitis. 2011 [cited 2020 Aug 27]. p. 344-7. Available from: https://www.journals. lww.com/dermatitis/Fulltext/2011/11000/Lavender.7.aspx. Accessed 31 Aug 2020

56. Sugiura M, Hayakawa R, Kato Y, Sugiura K, Hashimoto R. Results of patch testing with lavender oil in Japan. Contact Dermatitis [Internet]. John Wiley \& Sons, Ltd; 2000 [cited 2020 Aug 28];43:157-60. Available from: .https://www.wiley.com/10. 1034/j.1600-0536.2000.043003157.x. Accessed 31 Aug 2020

57. Warshaw EM, Zug KA, Belsito D V., Fowler JF, Dekoven JG, Sasseville D, et al. Positive patch-test reactions to essential oils in consecutive patients from North America and Central Europe. Dermatitis [Internet]. Lippincott Williams and Wilkins; 2017 [cited 2020 Aug 28];28:246-52. Available from: https://www. pubmed.ncbi.nlm.nih.gov/28614106/. Accessed 31 Aug 2020

58. Bingham LJ, Tam MM, Palmer AM, Cahill JL, Nixon RL. Contact allergy and allergic contact dermatitis caused by lavender: a retrospective study from an Australian clinic. Contact Dermatitis [Internet]. Blackwell Publishing Ltd; 2019 [cited 2020 Aug 28];81:37-42. Available from: https://www.pubmed.ncbi. nlm.nih.gov/30779160/. Accessed 31 Aug 2020

59. Brandáo FM. Occupational allergy to lavender oil. Contact Dermatitis [Internet]. Contact Dermatitis; 1986 [cited 2020 Aug 28];15:249-50. Available from: https://www.pubmed.ncbi. nlm.nih.gov/2948764/. Accessed 31 Aug 2020

60. Keane F, Smith H, White I, Rycroft R. Occupational allergic contact dermatitis in two aromatherapists. Contact Dermatitis. 2000;43:49-51.

61. Boonchai $\mathrm{W}$, Iamtharachai $\mathrm{P}$, Sunthonpalin P. Occupational allergic contact dermatitis from essential oils in aromatherapists. Contact Dermatitis [Internet]. John Wiley \& Sons, Ltd; 2007 [cited 2020 Aug 28];56:181-2. Available from: .https://www.wiley. com/10.1111/j.1600-0536.2007.01024.x. Accessed 31 Aug 2020

62. Trattner A, David M, Lazarov A. Occupational contact dermatitis due to essential oils. Contact Dermatitis [Internet]. John Wiley \& Sons, Ltd; 2008 [cited 2020 Aug 28];58:282-4. Available from: .https://www.wiley.com/10.1111/j.1600-0536.2007.01275.x. Accessed 31 Aug 2020

63. Navarro-Triviño FJ, Jadczak P, Ruiz-Villaverde R. Allergic contact dermatitis caused by Lavandula angustifolia and crossreaction with Citrus bergamia essential oils in an aromatherapist [Internet]. Int. J. Dermatol. Blackwell Publishing Ltd; 2020 [cited 2020 Aug 28]. Available from: https://www.pubmed.ncbi.nlm. nih.gov/32614066/. Accessed 31 Aug 2020

64. Corazza M, Amendolagine G, Borghi A, Toni G, Lauriola MM. Aromatherapy and occupational allergic contact dermatitis: two further cases caused by lavender oil and other essential oils. Contact Dermatitis [Internet]. Blackwell Publishing Ltd; 2019 [cited 2020 Aug 28];81:378-9. Available from: https://www. onlinelibrary.wiley.com/doi/abs/10.1111/cod.13328. Accessed 31 Aug 2020

65. Crawford GH, Katz KA, Ellis E, James WD. Use of aromatherapy products and increased risk of hand dermatitis in massage 
therapists. Arch Dermatol [Internet]. American Medical Association; 2004 [cited 2020 Aug 28];140:991-6. Available from: https://www.jamanetwork.com/. Accessed 31 Aug 2020

66. Schaller MS, Korting HC. Allergic airborne contact dermatitis from essential oils used in aromatherapy. Clin Exp Dermatol [Internet]. Blackwell Publishing Ltd; 1995 [cited 2020 Aug 28];20:143-5. Available from: https://www.pubmed.ncbi. nlm.nih.gov/8565250/. Accessed 31 Aug 2020

67. Hagvall L, Bråred Christensson J. Patch testing with main sensitizers does not detect all cases of contact allergy to oxidized lavender oil. Acta Derm Venereol [Internet]. Medical Journals/Acta D-V; 2016 [cited 2020 Aug 28];96:679-84. Available from: https://www.pubmed.ncbi.nlm.nih.gov/26671837/. Accessed 31 Aug 2020

68. Sköld M, Hagvall L, Karlberg AT. Autoxidation of linalyl acetate, the main component of lavender oil, creates potent contact allergens. Contact Dermatitis [Internet]. Contact Dermatitis; 2008 [cited 2020 Aug 28];58:9-14. Available from: https://www.pubmed. ncbi.nlm.nih.gov/18154552/. Accessed 31 Aug 2020

69. de Groot AC, Schmidt E. Essential Oils, Part IV. Dermatitis [Internet]. Lippincott Williams and Wilkins; 2016 [cited 2020 Aug 28];27:170-5. Available from: http://www.journals.lww. com/01206501-201607000-00003. Accessed 31 Aug 2020

70. Bråred Christensson J, Karlberg AT, Andersen KE, Bruze M, Johansen JD, Garcia-Bravo B, et al. Oxidized limonene and oxidized linalool - concomitant contact allergy to common fragrance terpenes. Contact Dermatitis [Internet]. Blackwell Publishing Ltd; 2016 [cited 2020 Oct 15];74:273-80. Available from: https:// www.pubmed.ncbi.nlm.nih.gov/26918793/. Accessed 31 Aug 2020

71. De Groot A. Linalool Hydroperoxides [Internet]. Dermatitis. Lippincott Williams and Wilkins; 2019 [cited 2020 Oct 26]. p. 243-6. Available from: https://www.pubmed.ncbi.nlm.nih.gov/ 31313746/. Accessed 31 Aug 2020

72. De Groot A. Limonene Hydroperoxides [Internet]. Dermatitis. Lippincott Williams and Wilkins; 2019 [cited 2020 Oct 26]. p. 331-5. Available from: https://www.pubmed.ncbi.nlm.nih.gov/ 31433385/. Accessed 31 Aug 2020

73. Pesonen M, Suomela S, Kuuliala O, Henriks-Eckerman ML, Aalto-Korte K. Occupational contact dermatitis caused by D -limonene. Contact Dermatitis [Internet]. Blackwell Publishing Ltd; 2014 [cited 2020 Oct 15];71:273-9. Available from: https:// www.pubmed.ncbi.nlm.nih.gov/25141986/. Accessed 31 Aug 2020

74. Foti C, Zambonin CG, Conserva A, Casulli C, D’Accolti L, Angelini G. Occupational contact dermatitis to a limonene-based solvent in a histopathology technician. Contact Dermatitis [Internet]. Contact Dermatitis; 2007 [cited 2020 Oct 15];56:10912. Available from: https://www.pubmed.ncbi.nlm.nih.gov/ 17244081/. Accessed 31 Aug 2020

75. Guarneri F, Barbuzza O, Vaccaro M, Galtieri G. Allergic contact dermatitis and asthma caused by limonene in a labourer handling citrus fruits. Contact Dermatitis [Internet]. Contact Dermatitis; 2008 [cited 2020 Oct 15];58:315-6. Available from: https:// www.pubmed.ncbi.nlm.nih.gov/18416769/. Accessed 31 Aug 2020

76. Rastogi SC, Heydorn S, Johansen JD, Basketter DA. Fragrance chemicals in domestic and occupational products. Contact Dermatitis [Internet]. John Wiley \& Sons, Ltd; 2001 [cited 2020 Oct 15];45:221-5. Available from: https://www.onlinelibrary. wiley.com/doi/full/10.1034/j.1600-0536.2001.450406.x. Accessed 31 Aug 2020

77. Herman A, Aerts O, de Montjoye L, Tromme I, Goossens A, Baeck M. Isothiazolinone derivatives and allergic contact dermatitis: a review and update [Internet]. J. Eur. Acad. Dermatology Venereol. Blackwell Publishing Ltd; 2019 [cited 2020 Oct 13]. p.
267-76. Available from: https://www.onlinelibrary.wiley.com/ doi/full/10.1111/jdv.15267. Accessed 31 Aug 2020

78. Uter W, Aalto-Korte K, Agner T, Andersen KE, Bircher AJ, Brans $\mathrm{R}$, et al. The epidemic of methylisothiazolinone contact allergy in Europe: follow-up on changing exposures. J Eur Acad Dermatology Venereol [Internet]. Blackwell Publishing Ltd; 2020 [cited 2020 Oct 14];34:333-9. Available from: https:/ www.pubmed.ncbi.nlm.nih.gov/31419348/. Accessed 31 Aug 2020

79. Schwensen JF, Friis UF, Menné T, Flyvholm MA, Johansen JD. Contact allergy to preservatives in patients with occupational contact dermatitis and exposure analysis of preservatives in registered chemical products for occupational use. Int Arch Occup Environ Health [Internet]. Springer Verlag; 2017 [cited 2020 Oct 14];90: 319-33. Available from: https://www.link.springer.com/article/ 10.1007/s00420-017-1203-5. Accessed 31 Aug 2020

80. Schnuch A, Schubert S, Lessmann H, Geier J, Beiteke U, Dissemond $\mathrm{J}$, et al. The methylisothiazolinone epidemic goes along with changing patients' characteristics - after cosmetics, industrial applications are the focus. Contact Dermatitis [Internet]. Blackwell Publishing Ltd; 2020 [cited 2020 Oct 13];82:87-93. Available from: https://www.onlinelibrary. wiley.com/doi/abs/10.1111/cod.13414. Accessed 31 Aug 2020

81. Zirwas MJ, Hamann D, Warshaw EM, Maibach HI, Taylor JS, Sasseville D, et al. Epidemic of isothiazolinone allergy in North America: prevalence data from the North American contact dermatitis group, 2013-2014. Dermatitis [Internet]. Lippincott Williams and Wilkins; 2017 [cited 2020 Oct 13];28:204-9. Available from: https://www.pubmed.ncbi.nlm.nih.gov/ 28509715/. Accessed 31 Aug 2020

82. Hollins LC, Hallock K, Disse M, Chu C, Szollas R, Marks J, et al. Occupationally induced allergic contact dermatitis to methylchloroisothiazolinone/methylisothiazolinone among water bottle plant workers. Dermatitis [Internet]. Lippincott Williams and Wilkins; 2020 [cited 2020 Oct 14];31:265-7. Available from: https://www.pubmed.ncbi.nlm.nih.gov/32049715/. Accessed 31 Aug 2020

83. Tous-Romero F, Sánchez-Velázquez A, Penalba-Torres M, de Frutos Ortiz J. Allergic contact dermatitis to a rubber assembly lubricant. Contact Dermatitis [Internet]. Blackwell Publishing Ltd; 2020 [cited 2020 Oct 14];cod.13579. Available from: https:// www.onlinelibrary.wiley.com/doi/abs/10.1111/cod.13579. Accessed 31 Aug 2020

84. Franken SM, van der Waal RIF, Rustemeyer T. Occupational contact dermatitis caused by "Chrysal flower food." Contact Dermatitis [Internet]. Blackwell Publishing Ltd; 2019 [cited 2020 Oct 14];81:400-1. Available from: https://www.ncbi.nlm. nih.gov/pmc/articles/PMC6852493/. Accessed 31 Aug 2020

85. Tramontana M, Hansel K, Bianchi L, Foti C, Romita P, Stingeni L. Occupational allergic contact dermatitis from a glue: concomitant sensitivity to "declared" isothiazolinones and "undeclared" (meth)acrylates. Contact Dermatitis [Internet]. Blackwell Publishing Ltd; 2020 [cited 2020 Oct 14];83:150-2. Available from: https://www.onlinelibrary.wiley.com/doi/abs/10.1111/cod. 13569. Accessed 31 Aug 2020

86. Marrero-Alemán G, Saavedra Santana P, Liuti F, Hernández N, López-Jiménez E, Borrego L. The role of cleaning products in epidemic allergic contact dermatitis to methylchloroisothiazolinone/ methylisothiazolinone. Dermatitis [Internet]. Lippincott Williams and Wilkins; 2018 [cited 2020 Oct 14];29:77-80. Available from: https://www.pubmed.ncbi.nlm.nih.gov/29494393/. Accessed 31 Aug 2020

87. Marrero-Alemán G, Borrego L, Antuña AG, Macías Montes A, Pérez Luzardo O. Isothiazolinones in cleaning products: analysis with liquid chromatography tandem mass spectrometry of samples from sensitized patients and market. Contact Dermatitis [Internet]. 
Blackwell Publishing Ltd; 2020 [cited 2020 Oct 14];82:94-100. Available from: https://www.pubmed.ncbi.nlm.nih.gov/ 31657463/. Accessed 31 Aug 2020

88. Todberg T, Opstrup MS, Johansen JD, Hald M. Occupational facial contact dermatitis caused by methylchloroisothiazolinone/ methylisothiazolinone in a stainless steel aerosol spray. Contact Dermatitis [Internet]. Blackwell Publishing Ltd; 2017 [cited 2020 Oct 14];77:173-4. Available from: .https://www.wiley.com/10. 1111/cod.12773. Accessed 31 Aug 2020

89. Corazza M, Forconi R, Bernardi T, Bianchi A, Scuderi V, Monti $\mathrm{A}$, et al. Occupational allergic contact dermatitis due to undeclared benzisothiazolinone in an emulsifying oil. Contact Dermatitis [Internet]. Blackwell Publishing Ltd; 2020 [cited 2020 Oct 14];cod.13559. Available from: https://www.onlinelibrary. wiley.com/doi/abs/10.1111/cod.13559. Accessed 31 Aug 2020

90. Corazza M, Amendolagine G, Cristofaro D, Bernardi T, Foti C, Romita P, et al. Occupational allergic contact dermatitis caused by isothiazolinones in ultrasound gel: 2 cases. Contact Dermatitis [Internet]. Blackwell Publishing Ltd; 2017 [cited 2020 Oct 14];77:337-8. Available from: https://www.pubmed.ncbi. nlm.nih.gov/29063693/. Accessed 31 Aug 2020

91. Lan J, Song Z, Miao X, Li H, Li Y, Dong L, et al. Skin damage among health care workers managing coronavirus disease-2019. J Am Acad Dermatol [Internet]. Mosby Inc.; 2020 [cited 2020 Aug 27];82:1215-6. Available from: https://www-ncbi-nlm-nihgov.library1.unmc.edu/pmc/articles/PMC7194538/. Accessed 31 Aug 2020

92. Zuo Y, Hua W, Luo Y, Li L. Skin reactions of N95 masks and medial masks among health-care personnel: a self-report questionnaire survey in China [Internet]. Contact Dermatitis. Blackwell Publishing Ltd; 2020 [cited 2020 Aug 27]. p. 145-7. Available from: https://www.ncbi.nlm.nih.gov/pmc/articles/PMC7262031/. Accessed 31 Aug 2020

93. Hu K, Fan J, Li X, Gou X, Li X, Zhou X. The adverse skin reactions of health care workers using personal protective equipment for COVID-19. Medicine (Baltimore) [Internet]. NLM (Medline); 2020 [cited 2020 Aug 31];99:e20603. Available from: https://www.pmc/articles/PMC7302613/?report=abstract. Accessed 31 Aug 2020

94. Lin P, Zhu S, Huang Y, Li L, Tao J, Lei T, et al. Adverse skin reactions among healthcare workers during the coronavirus disease 2019 outbreak: a survey in Wuhan and its surrounding regions [Internet]. Br. J. Dermatol. Blackwell Publishing Ltd; 2020 [cited 2020 Aug 27]. p. 190-2. Available from: https://www.ncbi. nlm.nih.gov/pmc/articles/PMC7262186/. Accessed 31 Aug 2020

95. Guertler A, Moellhoff N, Schenck TL, Hagen CS, Kendziora B, Giunta RE, et al. Onset of occupational hand eczema among healthcare workers during the SARS-CoV-2 pandemic: comparing a single surgical site with a COVID-19 intensive care unit. Contact Dermatitis [Internet]. Blackwell Publishing Ltd; 2020 [cited 2020 Oct 26];83:108-14. Available from: https://www. pubmed.ncbi.nlm.nih.gov/32452036/. Accessed 31 Aug 2020

96. Singh M, Pawar M, Bothra A, Maheshwari A, Dubey V, Tiwari A, et al. Personal protective equipment induced facial dermatoses in healthcare workers managing Coronavirus disease 2019 [Internet]. J. Eur. Acad. Dermatology Venereol. Blackwell Publishing Ltd; 2020 [cited 2020 Aug 27]. p. e378-80. Available from: https://www.ncbi. nlm.nih.gov/pmc/articles/PMC7272982/. Accessed 31 Aug 2020

97. Kadivar S, Belsito D V. Occupational dermatitis in health care workers evaluated for suspected allergic contact dermatitis. Dermatitis [Internet]. Lippincott Williams and Wilkins; 2015 [cited 2020 Aug 19];26:177-83. Available from: https://www. pubmed.ncbi.nlm.nih.gov/26172487/. Accessed 31 Aug 2020

98. Suneja T, Belsito D V. Occupational dermatoses in health care workers evaluated for suspected allergic contact dermatitis. Contact Dermatitis [Internet]. Contact Dermatitis; 2008 [cited 2020
Aug 20];58:285-90. Available from: https://www.pubmed-ncbinlm-nih-gov.libraryl.unmc.edu/18416759/. Accessed 31 Aug 2020

99. Nettis E, Colanardi MC, Soccio AL, Ferrannini A, Tursi A. Occupational irritant and allergic contact dermatitis among healthcare workers. Contact Dermatitis [Internet]. Contact Dermatitis; 2002 [cited 2020 Aug 20];46:101-7. Available from: https://www.pubmed-ncbi-nlm-nih-gov.library1.unmc.edu/ 11918604/. Accessed 31 Aug 2020

100. Rustemeyer T, Pilz B, Frosch PJ. Contact allergies in medical occupations [Internet]. Hautarzt. Hautarzt; 1994 [cited 2020 Aug 20]. p. 834-44. Available from: https://www.pubmed.ncbi. nlm.nih.gov/7843962/. Accessed 31 Aug 2020

101. Nettis E, Assennato G, Ferrannini A, Tursi A. Type I allergy to natural rubber latex and type IV allergy to rubber chemicals in health care workers with glove-related skin symptoms. Clin Exp Allergy [Internet]. Clin Exp Allergy; 2002 [cited 2020 Aug 17];32:441-7. Available from: https://www.pubmed.ncbi. nlm.nih.gov/11940076/. Accessed 31 Aug 2020

102. Dejonckheere G, Herman A, Baeck M. Allergic contact dermatitis caused by synthetic rubber gloves in healthcare workers: sensitization to 1,3-diphenylguanidine is common. Contact Dermatitis [Internet]. Blackwell Publishing Ltd; 2019 [cited 2020 Aug 27];81:167-73. Available from: https://www.pubmed.ncbi. nlm.nih.gov/30891769/. Accessed 31 Aug 2020

103. Hamnerius N, Svedman C, Bergendorff O, Björk J, Bruze M, Engfeldt M, et al. Hand eczema and occupational contact allergies in healthcare workers with a focus on rubber additives. Contact Dermatitis [Internet]. Blackwell Publishing Ltd; 2018 [cited 2020 Oct 15];79:149-56. Available from: https://www.pubmed.ncbi. nlm.nih.gov/29923205/. Accessed 31 Aug 2020

104. Warshaw EM, Schram SE, Maibach HI, Belsito DV, Marks JG, Fowler JF, et al. Occupation-related contact dermatitis in North American health care workers referred for patch testing: Crosssectional data, 1998 to 2004. Dermatitis. 2008;19:261-74.

105. Goodier MC, Ronkainen SD, Hylwa SA. Rubber accelerators in medical examination and surgical gloves. Dermatitis [Internet]. Lippincott Williams and Wilkins; 2018 [cited 2020 Oct 26];29: 66-76. Available from: https://www.pubmed.ncbi.nlm.nih.gov/ 29494385/. Accessed 31 Aug 2020

106. Isaac J, Goldminz AM, Scheinman PL. Don't forget the sponge [Internet]. Contact Dermatitis. Blackwell Publishing Ltd; 2019 [cited 2020 Oct 26]. p. 149-50. Available from: https://www. pubmed.ncbi.nlm.nih.gov/30891773/. Accessed 31 Aug 2020

107. MacGibeny MA, Wassef C. Preventing adverse cutaneous reactions from amplified hygiene practices during the COVID-19 pandemic: how dermatologists can help through anticipatory guidance. Arch Dermatol Res [Internet]. NLM (Medline); 2020 [cited 2020 Aug 27];1. Available from: https://www.pmc/articles/ PMC7210798/?report=abstract. Accessed 31 Aug 2020

108. US EPA O. List N: Disinfectants for Use Against SARS-CoV-2 (COVID-19). [cited 2020 Aug 27]; Available from: https://www. epa.gov/pesticide-registration/list-n-disinfectants-use-againstsars-cov-2-covid-19. Accessed 31 Aug 2020

109. Wentworth AB, Yiannias JA, Davis MDP, Killian JM. Benzalkonium chloride: a known irritant and novel allergen. Dermatitis [Internet]. Lippincott Williams and Wilkins; 2016 [cited 2020 Oct 14];27:14-20. Available from: https://www. pubmed.ncbi.nlm.nih.gov/26756511/. Accessed 31 Aug 2020

110. Isaac J, Scheinman PL. Benzalkonium chloride: an irritant and sensitizer. Dermatitis [Internet]. Lippincott Williams and Wilkins; 2017 [cited 2020 Oct 14];28:346-52. Available from: https://www. pubmed.ncbi.nlm.nih.gov/28885313/. Accessed 31 Aug 2020

111. Navarro-Triviño FJ, Merida-Fernández C, Ródenas-Herranz T, Ruiz-Villaverde R. Allergic contact dermatitis caused by elastic bands from FFP2 mask [Internet]. Contact Dermatitis. Blackwell Publishing Ltd; 2020 [cited 2020 Aug 25]. p. 168-9. Available 
from: https:/www.ncbi.nlm.nih.gov/pmc/articles/PMC7273080/. Accessed 31 Aug 2020

112. Kosann MK, Brancaccio R, Cohen D. Occupational allergic contact dermatitis in an obstetrics and gynecology resident. Am J Contact Dermat. 2003;14:217-8.

113. Al Badri FM. Surgical mask contact dermatitis and epidemiology of contact dermatitis in healthcare workers. Curr Allergy Clin Immunol. 2017;30:183-8.

114. Bothra A, Das S, Singh M, Pawar M, Maheswari A. Retroauricular dermatitis with vehement use of ear loop face masks during COVID-19 pandemic [Internet]. J. Eur. Acad. Dermatology Venereol. Blackwell Publishing Ltd; 2020 [cited 2020 Aug 25]. Available from: https://www.pubmed.ncbi.nlm. nih.gov/32491204/. Accessed 31 Aug 2020

115. Aerts O, Dendooven E, Foubert K, Stappers S, Ulicki M, Lambert J. Surgical mask dermatitis caused by formaldehyde (releasers) during the $<\mathrm{scp}>\mathrm{COVID}</ \mathrm{scp}>-19$ pandemic. Contact Dermatitis [Internet]. Blackwell Publishing Ltd; 2020 [cited 2020 Jul 14];cod.13626. Available from: https://www.onlinelibrary.wiley.com/doi/abs/10. 1111/cod.13626. Accessed 31 Aug 2020

116. Hua W, Zuo Y, Wan R, Xiong L, Tang J, Zou L, et al. Short-term skin reactions following use of N95 respirators and medical masks. Contact Dermatitis [Internet]. Blackwell Publishing Ltd; 2020 [cited 2020 Aug 25];83:115-21. Available from: https://www.pubmed.ncbi. nlm.nih.gov/32406064/. Accessed 31 Aug 2020

117. Donovan J, Skotnicki-Grant S. Allergic contact dermatitis from formaldehyde textile resins in surgical uniforms and nonwoven textile masks. Dermatitis [Internet]. Dermatitis; 2007 [cited 2020 Aug 27];18:40-4. Available from: https://www.pubmed.ncbi.nlm. nih.gov/17303043/. Accessed 31 Aug 2020

118. van Kudla Dono I, Holness LD, Skotniki-Grant S, Nethercott JR. Skin reactions following use of N95 facial masks. Dermatitis. 2007; 18:104

119. Xie Z, Yang YX, Zhang H. Mask-induced contact dermatitis in handling COVID-19 outbreak [Internet]. Contact Dermatitis. Blackwell Publishing Ltd; 2020 [cited 2020 Aug 27]. p. 166-7. Available from: https://www.ncbi.nlm.nih.gov/pmc/articles/ PMC7272860/. Accessed 31 Aug 2020

120. Yu J, Chen JK, Mowad CM, Reeder M, Hylwa S, Chisolm S, et al. Occupational dermatitis to facial personal protective equipment in healthcare workers: a systematic review. J Am Acad Dermatol [Internet]. Elsevier BV; 2020 [cited 2020 Oct 14]; Available from: https://www.pubmed.ncbi.nlm.nih.gov/33011325/. Accessed 31 Aug 2020

121. Nassau S, Fonacier L. Allergic Contact Dermatitis [Internet]. Med. Clin. North Am. W.B. Saunders; 2020 [cited 2020 Oct 15]. p. 6176. Available from: https://www.pubmed.ncbi.nlm.nih.gov/ 31757238/. Accessed 31 Aug 2020

122. Rundle CW, Presley CL, Militello M, Barber C, Powell DL, Jacob SE, et al. Hand hygiene during COVID-19: recommendations from the American Contact Dermatitis Society. J Am Acad Dermatol [Internet]. Elsevier BV; 2020 [cited 2020 Aug 27]; Available from: https://www.pubmed.ncbi.nlm.nih.gov/ 32707253/. Accessed 31 Aug 2020

123. Crepy MN, Lecuen J, Ratour-Bigot C, Stocks J, Bensefa-Colas L. Accelerator-free gloves as alternatives in cases of glove allergy in healthcare workers. Contact Dermatitis [Internet]. Blackwell Publishing Ltd; 2018 [cited 2020 Oct 26];78:28-32. Available from: https://www.pubmed.ncbi.nlm.nih.gov/28748553/. Accessed 31 Aug 2020

124. Pontén A, Dubnika I. Delayed reactions to reusable protective gloves. Contact Dermatitis [Internet]. Contact Dermatitis; 2009 [cited 2020 Oct 14];60:227-9. Available from: https://www. pubmed.ncbi.nlm.nih.gov/19338595/. Accessed 31 Aug 2020

125. VoPham T, Weaver MD, Hart JE, Ton M, White E, Newcomb PA. Effect of social distancing on COVID-19 incidence and mortality in the US. medRxiv Prepr Serv Heal Sci [Internet]. Cold Spring Harbor Laboratory Preprints; 2020 [cited 2020 Aug 23]; Available from: https://www.pmc/articles/PMC7310657/?report= abstract. Accessed 31 Aug 2020

126. Koo JR, Cook AR, Park M, Sun Y, Sun H, Lim JT, et al. Interventions to mitigate early spread of SARS-CoV-2 in Singapore: a modelling study. Lancet Infect Dis [Internet]. Lancet Publishing Group; 2020 [cited 2020 Aug 22];20:678-88. Available from: https://www.pubmed.ncbi.nlm.nih.gov/ 32213332/. Accessed 31 Aug 2020

127. Midander K, Hurtig A, Borg Tornberg A, Julander A. Allergy risks with laptop computers - nickel and cobalt release. Contact Dermatitis [Internet]. Blackwell Publishing Ltd; 2016 [cited 2020 Aug 23];74:353-9. Available from: .https://www.wiley.com/10. 1111/cod.12525. Accessed 31 Aug 2020

128. Jensen P, Jellesen MS, Moller P, Frankild S, Johansen JD, Menné T, et al. Nickel allergy and dermatitis following use of a laptop computer. J Am Acad Dermatol. Mosby Inc. 2012;67:e170-1.

129. Diepgen TL, Ofenloch RF, Bruze M, Bertuccio P, Cazzaniga S, Coenraads PJ, et al. Prevalence of contact allergy in the general population in different European regions. Br J Dermatol [Internet]. Blackwell Publishing Ltd; 2016 [cited 2020 Aug 23];174:319-29. Available from: https://www.pubmed.ncbi.nlm.nih.gov/ 26370659/. Accessed 31 Aug 2020

130. Yokota M, Fox LP, Maibach HI. Bilateral palmar dermatitis possible caused by computer wrist rest. Contact Dermatitis [Internet]. John Wiley \& Sons, Ltd; 2007 [cited 2020 Aug 23];57:192-3. Available from: .https://www.wiley.com/10.1111/j.1600-0536. 2007.01100.x. Accessed 31 Aug 2020

131. Garcia-Morales I, Garcia Bravo B, Camacho Martinez F. Occupational contact dermatitis caused by a personal-computer mouse mat. Contact Dermatitis [Internet]. John Wiley \& Sons, Ltd; 2003 [cited 2020 Aug 23];49:172-172. Available from: .https://www.wiley.com/10.1111/j.0105-1873.2003.0185p.x. Accessed 31 Aug 2020

132. Goossens A, Blondeel S, Zimerson E. Resorcinol monobenzoate: a potential sensitizer in a computer mouse. Contact Dermatitis [Internet]. John Wiley \& Sons, Ltd; 2002 [cited 2020 Aug 23];47:235-235. Available from: .https://www.wiley.com/ 10.1034/j.1600-0536.2002.470410.x. Accessed 31 Aug 2020

133. Li K, Barankin B. Cutaneous manifestations of modern technology use. J Cutan Med Surg [Internet]. SAGE PublicationsSage CA: Los Angeles, CA; 2011 [cited 2020 Aug 23];15:347-53. Available from: http://www.journals.sagepub.com/doi/10.2310/ 7750.2011.10053. Accessed 31 Aug 2020

134. Pföhler C, Körner R, Müller CSL, Vogt T. Occupational allergic contact dermatitis of the ears caused by thiurams in a headset. Contact Dermatitis [Internet]. John Wiley \& Sons, Ltd; 2011 [cited 2020 Aug 23];65:242-3. Available from: .https://www.wiley. com/10.1111/j.1600-0536.2011.01950.x. Accessed 31 Aug 2020

135. Jacob SE, Admani S. IPad - Increasing nickel exposure in children. Pediatrics [Internet]. American Academy of Pediatrics; 2014 [cited 2020 Aug 23];134:580. Available from: https://www. pediatrics.org/cgi/. Accessed 31 Aug 2020

Publisher's Note Springer Nature remains neutral with regard to jurisdictional claims in published maps and institutional affiliations. 